\title{
Prosedur Pembukaan Unit Usaha Syariah Pada Bank Konvensional
}

\author{
Wati Rahmi Ria
}

Dosen Bagian Keperdataan Fakultas Hukum Univeristas Lampung

\begin{abstract}
Abstrak
Pertumbuhan dan perkembangan perbankan yang begitu pesat membawa angina segar bagi para pelakunya, karena bank-bank yang pada umumnya operasional di tengah-tengah masyarakat mulai mencoba untuk merambah pada perbankan yang memiliki system syariah. Salah satu wujudnya adalah adanya bank konvensional yang membuka Unit Usaha Syariah (UUS). Untuk lebih mendorong terciptanya perbankan yang tangguh dan efisien diperlukan pengaturan mengenai pembukaan bank yang jelas dan memberikan kepastian hukum.
\end{abstract}

Kata Kunci : Bank Konvensional, Sistem Syariah, Unit Usaha Syariah.

\section{PENDAHULUAN}

Sebuah bank dinyatakan sebagai bank konvensional apabila aktivitas bank tersebut memobilisasi atau menerima dana dari masyarakat dan masyarakat diberi bunga kemudian dalam operasi atau penyaluran dananya pihak nasabah (masyarakat) oleh bank dikenakan bunga pinjaman. Bagi perbankan konvensional, selisih (spread) antara besarnya bunga yang dikenakan kepada para peminjam dana dengan imbalan bunga yang diberikan kepada para nasabah penyimpan dana itulah yang merupakan sumber keuntungan terbesar yang diperoleh.

Dengan kata lain Bank Konvensional yaitu sebuah bank yang bertugas menghimpun dan menyalurkan dana kepada masyarakat baik dalam bentuk kredit, tabungan, deposito dan lainlain. Namun bank konvensional yang menerapkan sistem bunga sangat bertolak belakang dengan keadaan masyarakat di Indonesia yang sebagian besar beragama Islam yang menolak akan sistem tersebut karena adanya riba dalam sistem tersebut.

Riba secara bahasa bermakna ziyadah (tambahan), dalam pengertian lain secara linguistik riba juga berarti tumbuh dan membesar. Adapun menurut istilah teknis, riba adalah pengambilan tambahan dari harta pokok atau modal secara batil.

Secara garis besar, riba dikelompokkan menjadi dua. Masing-masing adalah riba utangpiutang dan riba jual beli. Adapun kelompok pertama terbagi lagi menjadi riba qardh dan riba jahiliyyah. Kelompok kedua riba jual beli terbagi menjadi riba fadhl dan riba nasi'ah, berikut penjelasannya:

1. riba qardh, yaitu suatu manfaat atau tingkat kelebihan tertentu yang diisyaratkan terhadap yang berutang (muqtaridh);

2. riba jahiliyyah, yaitu utang dibayar lebih dari pokoknya karena si peminjam tidak mampu mambayar utangnya pada waktu yang ditetapkan;

3. riba $f a d h l$, yaitu pertukaran antar barang sejenis dengan kadar atau takaran yang berbeda, sedangkan 
barang yang dipertukarkan itu termasuk dalam jenis barang ribawi;

4. riba nasi'ah, yaitu penangguhan penyerahan atau penerimaan jenis barang ribawi yang dipertukarkan dengan jenis barang ribawi lainnya. Riba dalam nasi'ah muncul karena adanya perbedaan, perubahan, atau tambahan antara yang diserahkan saat ini dan yang diserahkan kemudian (Muhammad Syafi'i Antonio, 2001: 41).

Larangan riba terdapat dalam Al Quran surat Ali Imran ayat 130 dalam firmannya Allah SWT menyatakan "Hai orang-orang yang beriman, janganlah kamu memakan riba dengan berlipat ganda dan bertakwalah kamu kepada Allah supaya kamu mendapat keberuntungan".selain ayat dalam surat ersebut larangan riba juga terdapat pada surat ar Ruum ayat 39, an Nisaa' ayat 160-161 dan al Baqarah ayat 278-279.

Selain itu juga terdapat pada hadist salah satunya hadist yang diriwayatkan Bukhari no. 2145, kitab al-Wakalah yang diriwayatkan oleh Abu Said al-Khudri bahwa pada suatu ketika Bilal membawa barni (sejenis kurma berkualitas baik) kehadapan Rasulullah saw, dan beliau bertanya kepadanya, "Darimana engkau mendapatkannya? "Bilal menjawab,"Saya mempunyai sejumlah kurma dari jenis yang rendah mutunya dan menukarkannya dua sha'untuk satu sha'kurma jenis barni untuk dimakan oleh Rasulullah saw."Selepas itu Rasulullah saw terus berkata' "Hati-hati! Hati-hati! Ini sesungguhnya riba, ini sesungguhnya riba. Jangan berbuat begini, tetapi jika kamu membeli (kurma yang mutunya lebih tinggi), juallah kurma yang mutunya rendah untuk mendapatkan uang dan kemudian gunakanlah uang tersebut untuk membeli kurma yang bermutu tinggi itu" (Muhammad Syafi'i Antonio, 2001: 49-52). Adapun penjelasan di atas untuk menjelaskan bahwa riba adalah haram dan untuk itu diperlukan sebuah bank yang dalam prakteknya menerapkan sistem bagi hasil seperti bank syariah.

Dewasa ini hampir seluruh negara menggunakan sistem perekonomian yang dipisahkan dari ajaran agama, umat Islampun yang mempunyai kewajiban untuk taat pada perintah Allah Swt dan RasulNya banyak yang turut andil dalam penggunaan sistem perekonomian tersebut.

Islam sebagai salah satu ajaran yang mayoritas dianut oleh masyarakat Indonesia mengatur berbagai aspek kehidupan manusia termasuk aspek ekonomi. Pengaturan ini tentunya bertujuan untuk kehidupan yang damai, tentram dan bahagia tidak hanya di dunia tetapi juga kehidupan yang abadi di akhirat kelak.

Menurut Pasal 1 Ayat (7) Undang-Undang Nomor 21 Tahun 2008 Tentang Perbankan Syariah menyatakan bahwa Bank Syariah adalah bank yang menjalankan kegiatan usahanya berdasarkan prinsip syariah dan menurut jenisnya terdiri atas Bank Umum Syariah dan Bank Pembiayaan Rakyat Syariah. Bank Syariah adalah bank yang sistem operasionalnya berdasarkan pada prinsip-prinsip ekonomi Islam, yang bersumber pada Al-Quran, Sunnah dan Ijma para ulama (Wati Rahmi Ria, 2005: 74 ). Bank syariah menawarkan produk-produk 
perbankan syariah yaitu sebagai berikut:

\section{1. al-wadi'ah (simpanan),} merupakan titipan atau simpanan pada bank syariah. Prinsip alwadi'ah merupakan titipan murni dari satu pihak ke pihak lain, baik perorangan maupun badan hukum yang harus dijaga dan dikembalikan kapan saja bila si penitip menghendaki;

2. pembiayaan dengan bagi hasil bank syariah untuk penyaluran dana dikenal dengan istilah pembiayaan. Prinsip bagi hasil dalam bank syariah yang diterapkan dalam pembiayaan dapat dilakukan dalam 4 akad utama yaitu:

a. al-musyarakah, merupakan akad kerjasama antara dua pihak atau lebih untuk melakukan usaha tertentu;

b. al-mudharabah, merupakan akad kerjasama antara kedua belah pihak, dimana pihak pertama menyediakan seluruh modal dan pihak lain menjadi pengelola;

c. al-muza'arah, adalah kerjasama pengolahan pertanian antara pemilik lahan dengan penggarap lahan;

d. al-musaqoh, merupakan bagian dari al-muza'arah yaitu penggarap hanya bertanggung jawab atas penyiraman dan pemeliharaan dengan menggunakan dana dan peralatan mereka sendiri.

3. bai'al murabahah, merupakan kegiatan jual beli pada harga pokok dengan tambahan keuntungan yang disepakati;

4. bai'as-salam, merupakan pembelian barang yang diserahkan kemudian hari, sedangkan pembayaran dilakukan dimuka;
5. bai'al-istihna', merupakan bentuk khusus dari akad bai'assalam, oleh karena itu ketentuan dalam bai'al-istihna' mengikuti ketentuan dan aturan bai'assalam;

6. al-ijarah (leasing) merupakan akad pemindahan hak guna atas barang atau jasa, melalui pembayaran upah sewa, tanpa diikuti dengan pemindahan kepemilikan atas barang itu sendiri;

7. al-wakalah (amanat) atau wakilah merupakan penyerahan atau pendelegasian atau pemberian mandat dari satu pihak kepada pihak lain;

8. al-kafalah (garansi), merupakan jaminan yang diberikan penanggung kepada pihak ketiga untuk memenuhi kewajiban pihak kedua atau yang ditanggung;

9. al-hawalah, merupakan pengalihan utang dari orang yang berutang kepada orang lain yang wajib menanggungnya;

10. ar-rabn, merupakan kegiatan menahan salah satu harta milik si peminjam sebagai jaminan atas pinjaman yang diterimanya (Kasmir, 2002: 180-190).

Untuk lebih mendorong terciptanya perbankan yang tangguh dan efisien, diperlukan pengaturan mengenai pembukaan bank yang jelas dan memberikan kepastian hukum bagi para pelakunya. Melalui berbagai ketentuan yang diatur dalam Undang-Undang Nomor 10 Tahun 2008 Tentang Perbankan. Namun, menginggat kajian mengenai perbankan syariah khususnya UUS dalam Undang-Undang tersebut belum spesifik. Sehingga perlu diatur secara khusus dalam suatu UndangUndang tersendiri, maka pemerintah 
melalui Bank Indonesia mengeluarkan sebuah regulasi mengenai perbankan syariah dengan menerbitkan Undang-Undang Nomor 21 Tahun 2008 Tentang Perbankan Syariah, beserta peraturan pelaksananya yang lebih khusus mengatur tentang UUS, seperti Peraturan Bank Indonesia Nomor 6/24/PBI/2004 Tentang Bank Umum Yang Melaksanakan Kegiatan Usaha Berdasarkan Prinsip Syariah, Peraturan Bank Indonesia Nomor 7/13/PBI/ 2005 Tentang Kewajiban Penyediaan Modal Minimum Bank Umum Berdasarkan Prinsip Syariah, dan Peraturan Bank Indonesia Nomor 8/3/PBI/2006 Tentang Perubahan Kegiatan Usaha Bank Umum Konvensional Menjadi Bank Umum Yang Melaksanakan Kegiatan Usaha Berdasarkan Prinsip Syariah Dan Pembukaan Kantor Bank Yang Melaksanakan Kegiatan Usaha Berdasarkan Prinsip Syariah Oleh Bank Umum Konvensional. Tidak hanya itu karena UUS berbentuk Perseroan Terbatas, maka diatur dengan Undang-Undang Nomor 40 Tahun 2007 Tentang Perseroan Terbatas.

Berbagai peraturan tersebut diataslah yang akan dijadikan pedoman dalam pembukaan sistem syariah atau UUS pada bank, seperti bagaimana dengan prosedur bank konvensional yang membuka system syariah (UUS) yang terdiri dari pembuatan akta pendirian sistem syariah (Unit Usaha Syariah) di notaris, permohonan izin untuk memperoleh persetujuan prinsip pendirian sistem syariah (Unit Usaha Syariah), pengesahan akta pendirian sistem syariah (Unit Usaha Syariah) oleh Menteri Hukum dan Hak Asasi Manusia, pendaftaran dalam daftar perusahaan, pengumuman dalam
Tambahan Berita Negara, dan permohonan izin usaha untuk melakukan kegiatan usaha sistem syariah (Unit Usaha Syariah).

Berdasarkan uraian tersebut bagaimana prosedur pembukaan Unit Usaha Syariah pada Bank Konvensional?

\section{Pembahasan}

Prosedur pembukaan unit usaha syariah pada bank konvensional terdiri dari beberapa tahapan yaitu pembuatan akta pendirian sistem syariah (Unit Usaha Syariah) di Notaris, permohonan izin untuk memperoleh persetujuan prinsip pendirian sistem syariah (Unit Usaha syariah) kepada Direksi Bank Indonesia, pengesahan akta pendirian sistem syariah (Unit Usaha Syariah) oleh Menteri Hukum dan Hak Asasi Manusia, Pendaftaran dalam daftar perusahaan, pengumuman dalam Tambahan Berita Negara, dan permohonan izin usaha untuk melakukan kegiatan usaha sistem syariah (Unit Usaha Syariah) yang selanjutnya akan dibahas sbb:

\section{a. Pembuatan Akta Pendirian Sistem Syariah (UUS) di Notaris}

Tahapan pertama pembukaan system syariah (Unit Usaha Syariah) adalah pembuatan akta pendirian badan hukum UUS dihadapan Notaris. Pasal 7 Ayat (1) UndangUndang Nomor 40 Tahun 2007 Tentang Perseroan Terbatas menyatakan bahwa Perseroan didirikan oleh 2 (dua) orang atau lebih dengan akta notaris yang dibuat dalam bahasa Indonesia. Menurut Pasal 7 Ayat (1) di atas yang 
dimaksud dengan orang adalah orang perseorangan atau badan hukum. Badan hukum ini dibentuk berdasarkan perjanjian antara 2 (dua) orang atau lebih yang berarti mempunyai lebih dari satu orang pemegang saham. Akta pendirian itu merupakan perjanjian yang dibuat secara otentik yang memuat anggaran dasar yang telah disepakati dan ditandatangani oleh para pendiri UUS.

Berdasarkan ketentuan di atas dapat dijelaskan bahwa untuk mendirikan UUS berbentuk badan hukum Perseroan Terbatas para pendiri UUS harus menghadap notaris untuk minta dibuatkan akta otentik pendirian badan hukum UUS yang sekaligus memuat anggaran dasar UUS. Sejak akta pendirian ditandatangani oleh para pendiri, Selanjutnya akta pendirian badan hukum UUS dapat diperoleh dan terdapat hubungan kontrak antar pendiri dengan segala tanggung jawabnya. Hubungan kontrak tersebut belum menciptakan status badan hukum sebelum disahkan oleh Menteri Hukum dan Hak Asasi Manusia. Hal ini sesuai dengan Pasal 7 Ayat (4) Undang-Undang Nomor 40 Tahun 2007 Tentang Perseroan Terbatas yang menyatakan bahwa perseroan memperoleh status badan hukum pada tanggal diterbitkannya Keputusan Menteri mengenai pengesahan Badan Hukum Perseroan.

\section{b. Permohonan Izin Untuk Memperoleh Persetujuan Prinsip Pendirian Sistem Syariah (Unit Usaha Syariah)}

Tahapan kedua pendirian UUS adalah permohonan izin untuk memperoleh persetujuan prinsip, yaitu persetujuan untuk melakukan persiapan pendirian UUS. Permohonan untuk memperoleh persetujuan prinsip diajukan sekurang-kurangnya oleh seorang calon pemilik kepada direksi Bank Indonesia. Permohonan tersebut disampaikan kekantor pusat Bank Indonesia.

Hal ini sesuai dengan Pasal 6 Ayat (1) Peraturan Bank Indonesia Nomor 6/24/PBI/2004 Tentang Bank Umum Yang Melaksanakan Kegiatan Usaha Berdasarkan Prinsip Syariah menyatakan bahwa Permohonan untuk mendapatkan persetujuan prinsip sebagaimana dimaksud dalam Pasal 3 Ayat (2) huruf a diajukan sekurang-kurangnya oleh salah satu calon pemilik kepada Gubernur Bank Indonesia dan wajib disertai dengan:

1. rancangan akta pendirian badan hukum, termasuk rancangan anggaran dasar yang sekurangkurangnya memuat:

a) nama dan tempat kedudukan;

b) kegiatan usaha sebagai bank;

c) permodalan;

d) kepemilikan;

e) wewenang, tanggung jawab, dan masa jabatan Direksi serta dewan Komisaris;

f) penempatan dan tugas-tugas Dewan Pengawas Syariah.

2. data kepemilikan berupa:

a) daftar calon pemegang saham berikut rincian besarnya masing-masing kepemilikan saham bagi bank yang berbentuk hukum Perseroan Terbatas/Perusahaan Daerah;

b) daftar calon anggota berikut rincian jumlah simpanan pokok, simpanan wajib, serta daftar hibah bagi bank yang berbentuk hukum koperasi. 
3. daftar calon anggota Direksi, dewan Komisaris dan Dewan Pengawas Syariah disertai dengan:

a) pas foto 1 (satu) bulan terakhir ukuran 4 × $6 \mathrm{~cm}$;

b) fotokopi tanda pengenal yang dapat berupa Kartu Tanda Penduduk (KTP) atau paspor;

c) riwayat hidup;

d) contoh tanda tangan dan paraf;

e) fotokopi Kartu Izin Menetap sementara (KIMS) dan fotokopi surat izin bekerja dari instansi berwenang, bagi Warga Negara Asing;

f) surat pernyataan pribadi yang menyatakan tidak pernah melakukan tindakan tercela di bidang perbankan, keuangan, dan usaha lainnya, tidak pernah dihukum karena terbukti melakukan tindak pidana kejahatan, dan tidak sedang dalam masa pengenaan sanksi untuk dilarang menjadi pengurus bank sebagaimana diatur dalam ketentuan Penilaian Kemampuan dan Kepatutan (Fit and Proper Test) yang ditetapkan oleh Bank Indonesia.

g) surat pernyataan pribadi yang menyatakan bahwa yang bersangkutan tidak pernah dinyatakan pailit dan tidak pernah menjadi pemegang saham, anggota Direksi atau Komisaris yang dinyatakan bersalah yang menyebabkan perseroan dinyatakan pailit berdasar ketetapan pengadilan dalam waktu 5 (lima) tahun sebelum tanggal permohonan;

h) surat keterangan atau bukti tertulis dari tempat bekerja sebelumnya mengenai pengalaman operasional di bidang perbankan syariah bagi calon anggota Direksi atau bagi calon anggota dewan Komisaris yang telah berpengalaman;

i) surat keterangan dari lembaga pendidikan mengenai pendidikan perbankan syariah yang pernah diikuti bagi calon anggota Direksi atau bagi calon anggota dewan Komisaris yang belum berpengalaman;

j) surat pernyataan dari anggota dewan Komisaris bahwa yang bersangkutan tidak rangkap jabatan melebihi ketentuan:

1) sebagai anggota dewan Komisaris sebanyakbanyaknya pada 1 (satu) bank lain;

2) sebagai anggota dewan Komisaris, Direksi, atau Pejabat Eksekutif yang memerlukan tanggung jawab penuh sebanyakbanyaknya pada 2 (dua) lembaga/perusahaan lain bukan bank;

k) surat pernyataan dari anggota Direksi bahwa yang bersangkutan tidak rangkap jabatan sebagai anggota Direksi, Komisaris, atau Pejabat Eksekutif pada perusahaan dan atau lembaga lain;

1) surat pernyataan dari anggota Dewan Pengawas Syariah bahwa bersangkutan tidak rangkap jabatan 
sebagai anggota Dewan

Pengawas Syariah lebih dari 2 (dua) bank lain dan 2 (dua) lembaga keuangan syariah bukan bank;

m) surat pernyataan dari anggota Direksi dan dewan Komisaris bahwa yang bersangkutan tidak mempunyai hubungan keluarga dengan mayoritas anggota dewan komisaris/ dewan Direksi sampai dengan derajat kedua dengan sesama anggota dewan Komisaris atau anggota dewan Direksi;

n) surat pernyataan dari anggota Direksi bahwa yang bersangkutan baik secara sendiri-sendiri atau bersama-sama tidak memiliki saham melebihi $25 \%$ dari modal disetor pada suatu perusahaan lain;

Syarat-syarat tersebut harus dilengkapi, agar permohonan izin dapat diterima oleh Bank Indonesia.

\section{c. Pengesahan Akta Pendirian Sistem Syariah (Unit Usaha Syariah) Oleh Menteri Hukum Dan Hak Asasi Manusia}

Tahapan ketiga pendirian UUS adalah permohonan Pengesahan akta pendirian UUS oleh Menteri Hukum dan Hak Asasi Manusia. Pengesahan ini penting karena status badan hukum UUS dapat diperoleh setelah akta pendirian disahkan oleh Menteri Hukum dan Hak Asasi Manusia sesuai dengan Pasal 7 Ayat (4) Undang-Undang Nomor 40 Tahun 2007 Tentang Perseroan Terbatas. Pengesahan itu bertujuan untuk menjaga agar tidak terjadi penipuan dikemudian hari.
Menurut Pasal 9 UndangUndang Nomor Nomor 40 Tahun 2007 Tentang Perseroan Terbatas menyatakan bahwa untuk memperoleh keputusan Menteri mengenai pengesahan badan hukum perseroan sebagaimana dimaksud dalam Pasal 7 Ayat (4), pendiri bersama-sama mengajukan permohonan melalui jasa teknologi informasi sistem administrasi badan hukum secara elektronik kepada Menteri dengan mengisi format isian yang memuat sekurang-kurangnya:

1.nama dan tempat kedudukan perseroan;

2.jangka waktu berdirinya perseroan;

3.maksud dan tujuan serta kegiatan usaha perseroan;

4.jumlah modal dasar, modal ditempatkan, dan modal disetor;

5.alamat lengkap perseroan. Pasal 10 Ayat (1) UndangUndang Nomor 40 Tahun 2007 Tentang Perseroan Terbatas menyatakan bahwa permohonan untuk memperoleh keputusan Menteri sebagaimana dimaksud dalam Pasal 9 Ayat (1) UndangUndang Nomor 40 Tahun 2007 Tentang Perseroan Terbatas dan keterangan mengenai dokumen pendukung tidak sesuai dengan ketentuan peraturan perundangundangan, Menteri langsung memberitahukan penolakan beserta alasannya kepada pemohon secara elektronik setelah itu dalam jangka waktu paling lambat 30 (tiga puluh) hari terhitung sejak tanggal pernyataan tidak berkeberatan sebagaimana dimaksud pada Ayat (3).

Apabila semua persyaratan telah dipenuhi dan lengkap paling lambat 14 (empat belas) hari, Menteri menerbitkan keputusan tentang pengesahan badan hukum 
perseroan yang ditandatangani secara elektronik. Adanya jangka waktu tersebut menunjukkan bahwa pemerintah bersungguh-sungguh untuk memberikan pelayanan yang baik agar tidak ada kesalahan.

\section{d. Pendaftaran Dalam Daftar Perusahaan}

Tahapan yang keempat adalah pendaftaran akta pendirian beserta surat pengesahan dalam daftar perusahaan. Dalam Pasal 29 Ayat (1) Undang-Undang Nomor 40 Tahun 2007 Tentang Perseroan Terbatas menyatakan bahwa daftar perseroan diselenggarakan oleh Menteri. Menteri tersebut adalah Menteri Hukum dan Hak Asasi Manusia.

Kemudian dalam Pasal 29 Ayat

(2) Undang-Undang Nomor 40 Tahun 2007 Tentang Perseroan Terbatas menyatakan bahwa daftar perseroan sebagaimana dimaksud pada Ayat (1) memuat data tentang perseroan yang meliputi:

1. nama dan tempat kedudukan, maksud dan tujuan serta kegiatan usaha, jangka waktu pendirian, dan permodalan;

2. alamat lengkap perseroan sebagaimana dimaksud dalam pasal 5;

3. nomor dan tanggal akta pendirian dan keputusan menteri mengenai pengesahan badan hukum perseroan sebagaimana dimaksud dalam Pasal 7(4);

4. nomor dan tanggal akta perubahan anggaran dasar dan persetujuan Menteri sebagaimana maksud dalam pasal 23 Ayat (1);

5. nomor dan tanggal akta perubahan anggaran dasar dan tanggal penerimaan pemberita- huan oleh Menteri sebagaimana dimaksud dalam Pasal 23 (2);

6. nama dan tempat kedudukan notaris yang membuat akta pendirian dan akta perubahan anggaran dasar;

7. nama lengkap dan alamat pemegang saham, anggota direksi, dan anggota dewan komisaris perseroan;

8. nomor dan tanggal akta pembubaran atau nomor dan tanggal penetapan pengadilan tentang pembubaran perseroan yang telah diberitahukan kepada Menteri;

9. berakhirnya status badan hukum perseroan;

10. neraca dan laporan laba rugi dari tahun buku yang bersangkutan bagi perseroan yang wajib diaudit.

Pasal 29 Ayat (3) UndangUndang Nomor 40 Tahun 2007 Tentang Perseroan Terbatas menyatakan bahwa data perseroan sebagaimana dimaksud pada Ayat (2) dimasukkan dalam daftar perseroan pada tanggal yang bersamaan dengan tanggal:

1. keputusan Menteri mengenai pengesahan badan hukum perseroan, persetujuan atas perubahan anggaran dasar yang memerlukan persetujuan;

2. penerimaan pemberitahuan perubahan anggaran dasar yang tidak memerlukan persetujuan;

3. penerimaan pemberitahuan perubahan data perseroan yang bukan merupakan perubahan anggaran dasar.

Tujuan dari pendaftaran ini adalah untuk mencatat bahan-bahan keterangan yang diperbuat secara benar dari suatu perusahaan dan merupakan sumber informasi resmi untuk semua pihak yang 
berkepentingan mengenai identitas, data, serta keterangan lainnya tentang perusahaan yang tercantum dalam Daftar Perusahaan dalam rangka menjamin kepastian usaha.

\section{e. Pengumuman Dalam Tambahan Berita Negara}

$\begin{array}{ccr}\text { Tahapan } & \text { kelima } & \text { adalah } \\ \text { pengumuman } & \text { berdirinya } & \text { UUS }\end{array}$
dalam Tambahan Berita Negara Republik Indonesia. Hal ini sesuai dengan Pasal 30 Ayat (1) UndangUndang Nomor 40 Tahun 2007 Tentang Perseroan Terbatas yang menyatakan bahwa Menteri mengumumkan dalam Tambahan berita negara Republik Indonesia:

1. akta pendirian perseroan beserta keputusan Menteri sebagaimana dimaksud dalam Pasal 7 (4);

2. akta perubahan anggaran dasar perseroan beserta keputusan Menteri sebagaimana dimaksud dalam Pasal 21 Ayat (1);

3. akta perubahan anggaran dasar yang telah diterima pemberitahuannya oleh Menteri.

Pengumuman dilakukan oleh Menteri Hukum dan Hak Asasi Manusia dalam waktu paling lambat 14 (empat belas) hari terhitung sejak tanggal diterbitkannya keputusan Menteri. Pengumuman ini dilakukan oleh direksi UUS yang bersangkutan dan direksi bertanggung jawab atas pengumuman tersebut, dan bagaimana jika pengumuman tersebut tidak dilakukan, maka direksi bertanggung jawab penuh atas segala perbuatan yang dilakukan perseroan.

Tentang makna keharusan diumumkan dalam berita negara, kiranya kita semua sudah maklum yaitu sebagai publikasi yang lebih luas lagi. Dalam praktek, apa yang diumumkan dalam berita negara itu hanyalah berita tentang didirikannya PT disertai tentang identitas penting. Mengenai isi selengkapnya dari akta pendirian yang telah disahkan berikut bukti pendaftaran pada pengadilan dan petikan surat keputusan pengesahan Menteri yang bersangkutan dimuat dalam suatu lembaran tersendiri, yaitu apa yang dinamakan Tambahan Berita Negara. Untuk setiap 1 (satu) PT diterbitkan 1(satu) Tambahan Berita Negara (Rudhi Prasetya, 2001:152).

Maksud dari apa yang termuat di atas adalah agar masyarakat, khususnya pihak ketiga/pihak-pihak yang berkepentingan dapat mengetahui ketentuan-ketentuan anggaran dasar PT.

\section{f. Permohonan Izin Usaha Untuk Melakukan Kegiatan Usaha Sistem Syariah (Unit Usaha Syariah)}

Tahapan keenam adalah Permohonan izin usaha untuk melakukan kegiatan UUS.

Berdasarkan Pasal 3 Peraturan Bank Indonesia Nomor 8/3/PBI/2006 Tentang Perubahan Kegiatan Usaha Bank Umum Konvensional Menjadi Bank Umum Yang Melaksanakan Kegiatan Usaha Berdasarkan Prinsip Syariah dan Pembukaan Kantor Bank Yang Melaksanakan Kegiatan Usaha Berdasarkan Prinsip Syariah Oleh Bank Umum Konvensional menyatakan bahwa Permohonan izin perubahan kegiatan usaha diajukan oleh Bank kepada Gubernur Bank Indonesia dan wajib disertai dengan:

1. anggaran dasar Bank;

2. rancangan akta perubahan anggaran dasar yang paling kurang memuat:

a. nama dan tempat kedudukan; 
b. penegasan bahwa Bank melaksanakan Kegiatan Usaha Berdasarkan Prinsip Syariah;

c. permodalan dalam hal terjadi perubahan

d. kepemilikan dalam hal terjadi perubahan

e. wewenang, tanggung $\mathrm{j}$ awab, dan masa jabatan Direksi serta dewan komisaris dalam hal terjadi perubahan

f. penempatan Dewan Pengawas Syariah dan tugas-tugasnya yang telah disetujui oleh rapat umum pemegang saham dan dibuat dihadapan notaris dalam bahasa Indonesia.

3. notulen rapat umum pemegang saham;

4. data berupa:

a. daftar calon pemegang saham berikut rincian besarnya masing-masing kepemilikan saham bagi bank yang berbentuk hukum Perseroan terbatas/ Perusahaan Daerah;

b. daftar calon anggota berikut rincian jumlah simpanan pokok dan wajib, serta daftar hibah bagi bank yang berbentuk hukum koperasi; dalam hal terjadi perubahan kepemilikan.

5. daftar calon anggota Direksi, dewan Komisaris dan Dewan Pengawas Syariah disertai dengan:

a. pas foto 1 (satu) bulan terakhir ukuran 4 × $6 \mathrm{~cm}$;

b. fotokopi tanda pengenal yang dapat berupa Kartu Tanda Penduduk (KTP) atau paspor;

c. riwayat hidup; d. contoh tanda tangan dan paraf ;

e. Fotokopi kartu izin menetap sementara (KIMS) dan fotokopi surat izan bekerja dari instansi berwenang, bagi warga negara asing;

6. surat pernyataan pribadi yang menyatakan tidak pernah melakukan tindakan tercela di bidang perbankan, keuangan dan usaha lainnya tidak pernah dihukum karena terbukti melakukan tindak pidana kejahatan dan tidak sedang dalam masa pengenaan sanksi untuk dilarang menjadi pengurus bank sebagaimana diatur dalam ketentuan Penilaian Kemampuan dan Kepatutan (Fit and Proper Test) yang ditetapkan oleh Bank Indonesia;

7. surat pernyataan pribadi yang menyatakan bahwa yang bersangkutan tidak pernah dinyatakan pailit dan tidak pernah menjadi pemegang saham, anggota Direksi atau Komisaris yang dinyatakan bersalah menyebabkan suatu perseroan dinyatakan pailit berdasarkan ketetapan pengadilan dalam waktu 5 (lima) tahun sebelum tanggal pengajuan permohonan;

8. surat keterangan atau bukti tertulis dari bank tempat bekerja sebelumnya mengenai pengalaman operasional di bidang perbankan syariah bagi calon anggota Direksi atau bagi calon anggota dewan Komisaris yang telah berpengalaman;

9. surat keterangan dari lembaga pendidikan mengenai pendidikan perbankan syariah yang pernah diikuti bagi calon anggota 
Direksi atau bagi calon anggota dewan Komisaris yang belum berpengalaman;

10. surat pernyataan dari anggota dewan Komisaris bahwa yang bersangkutan tidak merangkap jabatan melebihi ketentuan sebagaimana dimaksud dalam Peraturan Bank Indonesia tentang Pelaksanaan Good Corporate Govenance yang berlaku bagi bank yang melaksanakan kegiatan usaha berdasarkan Prinsip Syariah;

11. surat pernyataan dari anggota Direksi bahwa yang bersangkutan tidak merangkap jabatan sebagai anggota Direksi, Komisaris, atau Pejabat Eksekutif pada bank, perusahaan dan atau lembaga lain sebagaimana dimaksud dalam Peraturan Bank Indonesia tentang Pelaksanaan Good Corporate Govenance yang berlaku bagi bank yang melaksanakan Kegiatan Usaha Berdasarkan Prinsip Syariah;

12. surat pernyataan dari anggota Direksi dan dewan Komisaris bahwa yang bersangkutan tidak mempunyai hubungan keluarga dengan mayoritas anggota dewan Komisaris/dewan Direksi sebagaimana dimaksud dalam Peraturan Bank Indonesia tentang Pelaksanaan Good Corporate Govenance yang berlaku bagi bank yang melaksanakan Kegiatan Usaha Berdasarkan Prinsip Syariah;

13. surat pernyataan dari anggota Direksi bahwa yang bersangkutan baik secara sendirisendiri maupun bersama-sama tidak memiliki saham melebihi $25 \%$ (dua puluh lima perseratus) dari modal disetor pada suatu perusahaan lain;
14. surat pernyataan dari anggota Dewan Pengawas Syariah bahwa yang bersangkutan tidak merangkap jabatan melebihi ketentuan rangkap jabatan sebagaimana diatur dalam Peraturan Bank Indonesia tentang bank umum yang melaksanakan kegiatan usaha berdasarkan prinsip syariah.

Semua kelengkapan tersebut wajib dilengkapi jika akan mengajukan izin usaha untuk melakukan kegiatan usaha UUS.

\section{Penutup}

Tahapan pertama pembukaan sistem syariah (Unit Usaha Syariah) adalah pembuatan akta pendirian badan hukum UUS dihadapan Notaris. Tahapan kedua pendirian UUS adalah permohonan izin untuk memperoleh persetujuan prinsip, yaitu persetujuan untuk melakukan persiapan pendirian UUS sesuai dengan Pasal 6 Ayat (1) Peraturan Bank Indonesia Nomor 6/24/PBI/2004 Tentang Bank Umum Yang Melaksanakan Kegiatan Usaha Berdasarkan Prinsip Syariah.

Tahapan ketiga pendirian UUS adalah permohonan Pengesahan akta pendirian UUS oleh Menteri Hukum dan Hak Asasi Manusia.

Tahapan keempat adalah pendaftaran akta pendirian beserta surat pengesahan dalam daftar perusahaan sesuai Pasal 29 Ayat (1) Undang-Undang Nomor 40 Tahun 2007.

$\begin{array}{ccc}\text { Tahapan } & \text { kelima adalah } \\ \text { pengumuman } & \text { berdirinya } & \text { UUS }\end{array}$ dalam Tambahan Berita Negara Republik Indonesia berdasarkan Pasal 30 Ayat (1) Undang-Undang Nomor 40 Tahun 2007. 
Tahapan keenam adalah Permohonan izin usaha untuk melakukan kegiatan UUS.

\section{Daftar Pustaka}

Antonio, Muhammad Syafii. 2001. Bank Syariah Dari Teori Ke Praktik. Jakarta: Gema Insani.

Muhammad, Abdulkadir. 2004. Hukum dan Penelitian Hukum. Bandung: PT. Citra Aditya Bakti.

Rahardja, Prathama. 1997. Uang \& Perbankan. Jakarta: Rineka Cipta.

Simorangkir, O.P. 2004. Pengantar Lembaga Keuangan Bank dan Non Bank, Bogor: Ghalia Indonesia.

Sumitro Warkum, 1997. Asas-Asas Perbankan Islam dan Lembaga-Lembaga Terkait di Indonesia. PT Raja Grafindo Persada, Jakarta

Suyatno, Thomas. 1994. Kelembagaan Perbankan. Jakarta: PT Gramedia Pustaka Utama.

Usman, Rachmadi. 2001. AspekAspek Hukum Perbankan Di Indonesia. Jakarta: PT Gramedia Pustaka Utama.

Ria, Wati Rahmi. 2005. Buku Ajar Hukum Perbankan Islam. Bandar Lampung: Sinar Sakti.

Undang-Undang Nomor 10 Tahun 1998 Tentang Perbankan.

Undang-Undang Nomor 21 Tahun 2008 Tentang Perbankan Syariah. 